\title{
Front Matter: Volume 8903
}

, "Front Matter: Volume 8903," Proc. SPIE 8903, Photonics Applications in Astronomy, Communications, Industry, and High-Energy Physics Experiments 2013, 890301 (14 November 2013); doi: 10.1117/12.2049644

SPIE Event: Photonics Applications in Astronomy, Communications, Industry, and High-Energy Physics Experiments 2013, 2013, Wilga, Poland 


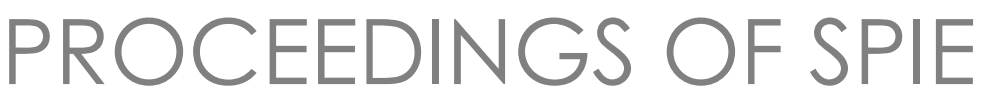

\title{
Photonics Applications in Astronomy, Communications, Industry, and High-Energy Physics Experiments 2013
}

\author{
Ryszard S. Romaniuk \\ Editor \\ 27 May-2 June 2013 \\ Wilga, Poland \\ Organized by \\ Institute of Electronic Systems, Faculty of Electronics and Information Technologies, \\ Warsaw University of Technology (Poland) \\ Sponsored by \\ PSP-Photonics Society of Poland \\ SPIE \\ Committee of Electronics and Telecommunications, Polish Academy of Sciences \\ EUCARD-European Coordination of Accelerator R\&D (CERN, EU FP7) \\ EUCARD²_Enhanced European Coordination of Accelerator R\&D (CERN, EU FP7) \\ TIARA-Test Infrastructure and Accelerator Research Area Preparatory Phase \\ IEEE Poland Section \\ PKOpto-Polish Committee of Optoelectronics of SEP \\ Published by \\ SPIE
}

Volume 8903

Proceedings of SPIE 0277-786X, V. 8903

SPIE is an international society advancing an interdisciplinary approach to the science and application of light.

Photonics Applications in Astronomy, Communications, Industry, and High-Energy Physics Experiments 2013, edited by Ryszard S. Romaniuk, Proc. of SPIE Vol. 8903, 890301

(C) 2013 SPIE · CCC code: 0277-786X/13/\$18 · doi: 10.1117/12.2049644

Proc. of SPIE Vol. $8903890301-1$ 
The papers included in this volume were part of the technical conference cited on the cover and title page. Papers were selected and subject to review by the editors and conference program committee. Some conference presentations may not be available for publication. The papers published in these proceedings reflect the work and thoughts of the authors and are published herein as submitted. The publisher is not responsible for the validity of the information or for any outcomes resulting from reliance thereon.

Please use the following format to cite material from this book:

Author(s), "Title of Paper," in Photonics Applications in Astronomy, Communications, Industry, and High-Energy Physics Experiments 2013, edited by Ryszard S. Romaniuk, Proceedings of SPIE Vol. 8903 (SPIE, Bellingham, WA, 2013) Article CID Number.

ISSN: 0277-786X

ISBN: 9780819497857

Published by

SPIE

P.O. Box 10, Bellingham, Washington 98227-0010 USA

Telephone +1 3606763290 (Pacific Time) · Fax +1 3606471445

SPIE.org

Copyright @ 2013, Society of Photo-Optical Instrumentation Engineers.

Copying of material in this book for internal or personal use, or for the internal or personal use of specific clients, beyond the fair use provisions granted by the U.S. Copyright Law is authorized by SPIE subject to payment of copying fees. The Transactional Reporting Service base fee for this volume is $\$ 18.00$ per article (or portion thereof), which should be paid directly to the Copyright Clearance Center (CCC), 222 Rosewood Drive, Danvers, MA 01923. Payment may also be made electronically through CCC Online at copyright.com. Other copying for republication, resale, advertising or promotion, or any form of systematic or multiple reproduction of any material in this book is prohibited except with permission in writing from the publisher. The CCC fee code is 0277-786X/13/\$18.00.

Printed in the United States of America.

Publication of record for individual papers is online in the SPIE Digital Library.

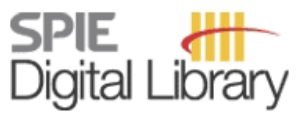

SPIEDigitalLibrary.org

Paper Numbering: Proceedings of SPIE follow an e-First publication model, with papers published first online and then in print and on CD-ROM. Papers are published as they are submitted and meet publication criteria. A unique, consistent, permanent citation identifier (CID) number is assigned to each article at the time of the first publication. Utilization of CIDs allows articles to be fully citable as soon as they are published online, and connects the same identifier to all online, print, and electronic versions of the publication. SPIE uses a six-digit CID article numbering system in which:

- The first four digits correspond to the SPIE volume number.

- The last two digits indicate publication order within the volume using a Base 36 numbering

system employing both numerals and letters. These two-number sets start with 00, 01, 02, 03, 04, 05, 06, 07, 08, 09, 0A, 0B ... 0Z, followed by 10-1Z, 20-2Z, etc.

The CID Number appears on each page of the manuscript. The complete citation is used on the first page, and an abbreviated version on subsequent pages. Numbers in the index correspond to the last two digits of the six-digit CID Number. 


\title{
Contents
}

\section{Part One}

\author{
xiii Conference Committee
}

$\mathrm{xv}$ Introduction

\section{PHOTONICS APPLICATIONS AND WEB ENGINEERING: WILGA 2013 SYMPOSIUM}

890302 Advanced photonic, electronic, and web engineering systems: WILGA Symposium, January 2013 [8903-33]

R. S. Romaniuk, Warsaw Univ. of Technology (Poland)

890303 Photonics applications and web engineering: WILGA May 2013 (Invited Paper) [8903-74]

R. S. Romaniuk, Warsaw Univ. of Technology (Poland)

890304 Development of optical sciences in Poland [8903-81]

R. S. Romaniuk, Warsaw Univ. of Technology (Poland)

\section{OPTICAL SCIENCE AND TECHNOLOGY}

890305 Surface shape measurement of specular objects using laser deflectometry [8903-5] J. Michoński, K. Mularczyk, R. Sitnik, Warsaw Univ. of Technology (Poland)

890306 Visible emission in $\mathrm{Sm}^{3+}$ and $\mathrm{Tb}^{3+}$ doped phosphate glass excited by UV radiation [8903-6] J. Zmojda, D. Dorosz, M. Kochanowicz, P. Miluski, K. Czajkowski, T. Ragin, Bialystok Univ. of Technology (Poland)

890307 Upconversion luminescence in tellurite glass codoped with $\mathrm{Yb}^{3+} / \mathrm{Ho}^{3+}$ ions [8903-7] D. Dorosz, J. Żmojda, M. Kochanowicz, W. Mazerski, Bialystok Univ. of Technology (Poland)

890308 Modelling of optical characteristics of nanocomposite C-Pd thin films by the method of single expression [8903-9]

H. V. Baghdasaryan, T. M. Knyazyan, State Engineering Univ. of Armenia (Armenia)

890309 Properties of the carbon-palladium nanocomposites studied by Raman spectroscopy method [8903-10]

R. Belka, M. Suchańska, Kielce Univ. of Technology (Poland)

$8903 \mathrm{OA}$ Analysis of upconversion luminescence in $\mathrm{Yb}^{3+} / \mathrm{Er}^{3+}$ co-doped tellurite optical fiber [8903-11]

W. Mazerski, M. Kochanowicz, D. Dorosz, Bialystok Univ. of Technology (Poland)

8903 OB Analysis of optical properties of fullerene-palladium nanostructures using effective medium theory [8903-12]

R. Belka, Kielce Univ. of Technology (Poland) 
8903 OC Optical fibre temperature sensor based on fluorescein and rhodamine codoped polymer layer [8903-15]

P. Miluski, D. Dorosz, M. Kochanowicz, J. Żmojda, Bialystok Univ. of Technology (Poland)

8903 OD Temperature characteristics of $p$ - $n$ junction high power LEDs in the typical operating conditions [8903-17]

Ł. Budzyński, K. Iwanowicz, M. Zajkowski, Bialystok Univ. of Technology (Poland)

8903 OE Development of multi-touch panel backlight system [8903-18]

J. Chomiczewski, M. Długosz, G. Godlewski, M. Kochanowicz, Bialystok Univ. of Technology (Poland)

8903 OF NIR-Vis-UV permittivity of nanoporous C-Pd thin films determined using spectroscopic ellipsometry [8903-19]

A. A. Wronkowska, G. Czerniak, A. Wronkowski, Univ. of Technology and Life Sciences (Poland); E. Czerwosz, E. Kowalska, Tele\&Radio Research Institute (Poland)

8903 OG Effect of temperature on luminescent properties of an antimony-silicate glass co-doped with $\mathrm{Yb}^{3+}$ and $\mathrm{Tm}^{3+}$ [8903-20]

K. Czajkowski, M. Kochanowicz, J. Zmojda, D. Dorosz, T. Ragin, P. Miluski, Bialystok Univ. of Technology (Poland)

$8903 \mathrm{OH} \quad$ Large-area transparent in visible range silicon carbide photodiode [8903-37] M. Borecki, Warsaw Univ. of Technology (Poland); A. Kociubiński, M. Duk, Lublin Univ. of Technology (Poland); N. Kwietniewski, Warsaw Univ. of Technology (Poland); M. L. Korwin-Pawlowski, Univ. du Québec en Outaouais (Canada); P. Doroz, J. Szmidt, Warsaw Univ. of Technology (Poland)

$890301 \quad$ Disparity map estimation using image pyramid [8903-48]

M. Roszkowski, Warsaw Univ. of Technology (Poland)

8903 0J Bitrate estimation for P-type frames in rate control process [8903-49]

M. Wieczorek, Warsaw Univ. of Technology (Poland)

8903 OK UAS imaging for archaeological survey and documentation [8903-53]

S. Esposito, P. Fallavollita, Univ. degli Studi di Roma La Sapienza (Italy); M. G. Melis, Univ. degli Studi di Sassari (Italy); M. Balsi, Univ. degli Studi di Roma La Sapienza (Italy);

S. Jankowski, Warsaw Univ. of Technology (Poland)

$8903 \mathrm{OL} \quad$ Review on developments in LIS (laser ion source) at the IPPLM and its possible applications in photonics [8903-54]

P. Gasior, M. Rosinski, Institute of Plasma Physics and Laser Microfusion (Poland)

8903 OM Algorithms for false event recognition in the Pi of the Sky system [8903-59]

L. Obara, A. F. Żarnecki, Univ. of Warsaw (Poland)

8903 ON Can ICAN can CERN into a can?: review study (Invited Paper) [8903-60]

P. Gasior, Institute of Plasma Physics and Laser Microfusion (Poland) 
$890300 \quad$ Photometric analysis of Pi of the Sky data [8903-125]

R. Opiela, Ctr. for Theoretical Physics (Poland); K. Małek, Ctr. for Theoretical Physics (Poland) and Nagoya Univ. (Japan); L. Mankiewicz, M. Siudek, Ctr. for Theoretical Physics (Poland); M. Sokołowski, National Ctr. for Nuclear Research (Poland), Curtin Univ. (Australia), and ARC Ctr. of Excellence for All-Sky Astrophysics (Australia); A. F. Żarnecki, Univ. of Warsaw (Poland)

8903 OP European X-Ray Free Electron Laser (EXFEL): local implications [8903-68]

R. S. Romaniuk, Warsaw Univ. of Technology (Poland)

89030 Optical microphone based on Sagnac interferometer with polarization maintaining optical fibers [8903-71]

K. Markowski, J. Turkiewicz, Warsaw Univ. of Technology (Poland); T. Osuch, Warsaw Univ. of Technology (Poland) and National Institute of Telecommunications (Poland)

8903 OR Evaluation of active appearance models in varying background conditions [8903-75] M. Kowalski, J. Naruniec, Warsaw Univ. of Technology (Poland)

8903 OS Validation of the automated system for simultaneous spectral transmission/reflection and dispersion characteristics measurement of fiber Bragg gratings and optical fibers [8903-76] D. Herman, Warsaw Univ. of Technology (Poland); T. Osuch, Warsaw Univ. of Technology (Poland) and National Institute of Telecommunications (Poland); T. Kossek, National Institute of Communications (Poland)

8903 OT The first release and preliminary analysis of Pi of the Sky data in R filter [8903-77] M. Siudek, Ctr. for Theoretical Physics (Poland); A. Ćwiek, National Ctr. for Nuclear Research (Poland); L. Mankiewicz, R. Opiela, Ctr. for Theoretical Physics (Poland); F. Żarnecki, Univ. of Warsaw (Poland)

8903 OU Modeling of fiber Bragg gratings written in tapered optical fibers [8903-79] K. Markowski, Warsaw Univ. of Technology (Poland); T. Osuch, Warsaw Univ. of Technology (Poland) and National Institute of Telecommunications (Poland)

$8903 \mathrm{OV}$ Technology and characterization of 4H-SiC p-i-n junctions [8903-82] A. Kociubiński, M. Duk, M. Masłyk, Lublin Univ. of Technology (Poland); N. Kwietniewski, M. Sochacki, M. Borecki, Warsaw Univ. of Technology (Poland); M. Korwin-Pawłowski, Univ. du Québec en Outaouais (Canada)

8903 OW Spectral transmission characteristics of weakly tilted and tilted chirped fiber gratings: comparative studies [8903-91]

T. Osuch, Warsaw Univ. of Technology (Poland) and National Institute of Telecommunications (Poland); T. Jurek, K. Jędrzejewski, Warsaw Univ. of Technology (Poland)

8903 0X Analysis of Brown camera distortion model [8903-92]

A. Nowakowski, W. Skarbek, Warsaw Univ. of Technology (Poland)

8903 OY Linear discriminant analysis for face recognition: comparison of subspace approach with regularization method [8903-94]

D. Grzywczak, W. Skarbek, Warsaw Univ. of Technology (Poland) 
$8903 \mathrm{OZ}$ On application of image analysis and natural language processing for music search [8903-95]

G. Gwardys, Warsaw Univ. of Technology (Poland)

890310 Prompt searches for optical signals from gravitational wave transient candidates with Pi of the Sky [8903-96]

A. Zadrożny, National Ctr. for Nuclear Research (Poland); M. Sokołowski, National Ctr. for Nuclear Research (Poland), Curtin Univ. (Australia), and ARC Ctr. of Excellence for All-Sky Astrophysics (Australia); R. Opiela, Ctr. for Theoretical Physics (Poland); Ł. Obara, Univ. of Warsaw (Poland)

890311 Short period pulsating stars: some theoretical issues [8903-102]

A. Majczyna, National Ctr. for Nuclear Research (Poland); M. Należyty, Warsaw Univ. Astronomical Observatory (Poland)

890312 Pi of the Sky-robotic telescope [8903-98]

A. Ćwiek, T. Batsch, National Ctr. for Nuclear Research (Poland); H. Czyrkowski, M. Ćwiok, R. Dąbrowski, Univ. of Warsaw (Poland); G. Kasprowicz, Warsaw Univ. of Technology (Poland); A. Majcher, National Ctr. for Nuclear Research (Poland); K. Małek, Ctr. for Theoretical Physics (Poland) and Nagoya Univ. (Japan); L. Mankiewicz, Ctr. for Theoretical Physics (Poland); K. Nawrocki, National Ctr. for Nuclear Research (Poland); Ł. Obara, Univ. of Warsaw (Poland); R. Opiela, Ctr. for Theoretical Physics (Poland); L. W. Piotrowski, Univ. of Warsaw (Poland) and RIKEN (Japan); M. Siudek, Ctr. for Theoretical Physics (Poland); M. Sokołowski, National Ctr. for Nuclear Research (Poland), Curtin Univ. (Australia), and ARC Ctr. of Excellence for All-Sky Astrophysics (Australia); R. Wawrzaszek, Space Research Ctr. (Poland); A. F. Żarnecki, Univ. of Warsaw (Poland)

\section{BIOMEDICAL SCIENCES AND TECHNOLOGIES}

890313 Mechatronics in monitoring, simulation, and diagnostics of industrial and biological processes (Invited Paper) [8903-104]

N. Golnik, M. Dobosz, M. Jakubowska, J. M. Kościelny, M. Kujawińska, T. Pałko, B. Pułz, R. Sitnik, P. Wnuk, A. Woźniak, Warsaw Univ. of Technology (Poland)

890314 Design and construction of the artificial patient module for testing bioimpedance measuring devices [8903-8]

M. Młyńczak, K. Pariaszewska, Warsaw Univ. of Technology (Poland); W. Niewiadomski, Mossakowski Medical Research Ctr. (Poland); G. Cybulski, Warsaw Univ. of Technology (Poland) and Mossakowski Medical Research Ctr. (Poland)

890315 Digital stethoscope system: the feasibility of cardiac auscultation [8903-16]

K. Pariaszewska, M. Młyńczak, Warsaw Univ. of Technology (Poland); W. Niewiadomski, Mossakowski Medical Research Ctr. (Poland); G. Cybulski, Warsaw Univ. of Technology (Poland) and Mossakowski Medical Research Ctr. (Poland)

890316 The effect of body weight and posture on acceleration of platform vibrating plate [8903-23] R. Kozłowska, Warsaw Univ. of Technology (Poland); W. Niewiadomski, Mossakowski Medical Research Ctr. (Poland); R. Leonarcik, M. Żyliński, Warsaw Univ. of Technology (Poland); G. Cybulski, Warsaw Univ. of Technology (Poland) and Mossakowski Medical Research Ctr. (Poland) 
890317 The DNA assembler for next generation sequencers [8903-26]

J. Twardowski, R. Nowak, Warsaw Univ. of Technology (Poland)

890318 New tool to combine contigs by usage of paired-end tags [8903-27]

P. Piotrowski, R. Nowak, Warsaw Univ. of Technology (Poland)

890319 Algorithm to search for genomic rearrangements [8903-28]

K. Nałęcz-Charkiewicz, R. Nowak, Warsaw Univ. of Technology (Poland)

$89031 \mathrm{~A} \quad H e a d$ of the bed elevation angle recorder for intensive care unit [8903-31]

M. Krefft, Warsaw Univ. of Technology (Poland); A. Zamaro-Michalska, Medical Univ. of Warsaw (Poland); W. M. Zabołołny, W. Zaworski, A. Grzanka, Warsaw Univ. of Technology (Poland); T. Łazowski, Medical Univ. of Warsaw (Poland); M. Tavola, ASL3 Genovese (Italy); J. Siewiera, District Hospital, Bolesławiec (Poland); M. Mikaszewska-Sokolewicz, Medical Univ. of Warsaw (Poland)

8903 1B Design of a positioning system for soft-docking of an intraoperative electron accelerator (Invited Paper) [8903-55]

R. Soboń, National Ctr. for Nuclear Research (Poland) and Warsaw Univ. of Technology (Poland); A. Wysocka-Rabin, National Ctr. for Nuclear Research (Poland); N. Golnik, Warsaw Univ. of Technology (Poland)

$89031 \mathrm{C}$ Optoelectronic set for measuring the absorption spectrum of the thin biological media [8903-80]

L. Gryko, A. Zajac, M. Gilewski, Bialystok Univ. of Technology (Poland)

8903 ID Simplification of the kinematic model of human movement [8903-93]

J. J. Dusza, Warsaw Univ. of Technology (Poland); Z. M. Wawrzyniak, Warsaw Univ. of Technology (Poland) and Medical Univ. of Warsaw (Poland); D. del Prado Martinez, Univ. of Valladolid (Spain)

8903 IE ICT use for information management in healthcare system for chronic disease patient [8903-101]

Z. M. Wawrzyniak, Warsaw Univ. of Technology (Poland) and Medical Univ. of Warsaw

(Poland); M. Lisiecka-Biełanowicz, Medical Univ. of Warsaw (Poland)

\section{Part Two}

\section{ADVANCED ELECTRONIC AND PHOTONIC SYSTEMS}

8903 IF TIARA project (Invited Paper) [8903-123]

P. Malecki, Cracow Univ. of Technology (Poland)

8903 1G Thermodynamic modeling of enhanced superconducting cable insulation for the proposed upgrade of the LHC inner triplet $\mathrm{Nb}$-Ti quadrupole magnets [8903-124]

D. Bocian, The Henryk Niewodniczański Institute of Nuclear Physics (Poland) 
$89031 \mathrm{H} \quad$ Automatic resource identification for FPGA-based reconfigurable measurement and control systems with mezzanines in FMC standard [8903-13]

A. Wojenski, G. Kasprowicz, K. T. Pozniak, R. Romaniuk, Warsaw Univ. of Technology (Poland)

$890311 \quad$ Automatic HDL firmware generation for FPGA-based reconfigurable measurement and control systems with mezzanines in FMC standard [8903-14]

A. Wojenski, G. Kasprowicz, K. T. Pozniak, R. Romaniuk, Warsaw Univ. of Technology (Poland)

$89031 \mathrm{~J}$ Automatic configuration of FMC boards for FPGA-based reconfigurable measurement and control systems with mezzanines in FMC standard [8903-90]

A. Wojenski, G. Kasprowicz, K. T. Pozniak, Warsaw Univ. of Technology (Poland)

8903 1K Heavy stable charged particles search by RPC system at CMS detector at LHC accelerator at CERN [8903-22]

A. Zagoździńska, K. T. Poźniak, R. Romaniuk, Warsaw Univ. of Technology (Poland);

P. Zalewski, National Ctr. for Nuclear Research (Poland)

$89031 \mathrm{~L}$ Optimized ethernet transmission of acquired data from FPGA to embedded system [8903-29]

W. M. Zabołotny, Warsaw Univ. of Technology (Poland)

$89031 \mathrm{M}$ Tethered Forth system for FPGA applications [8903-30]

P. Goździkowski, W. M. Zabołotny, Warsaw Univ. of Technology (Poland)

$89031 \mathrm{~N} \quad$ Positive fractional linear electrical circuits [8903-35]

T. Kaczorek, Bialystok Univ. of Technology (Poland)

890310 Quantization selection in the high-throughput H.264/AVC encoder based on the RD [8903-36]

G. Pastuszak, Warsaw Univ. of Technology (Poland)

8903 IP Accelerator science and technology in Europe 2008-2017 [8903-39]

R. S. Romaniuk, Warsaw Univ. of Technology (Poland)

$89031 Q \quad$ EuCARD2: enhanced accelerator R\&D in Europe [8903-41]

R. S. Romaniuk, Warsaw Univ. of Technology (Poland)

8903 IR Time-domain simulation of integrated circuits with lossy nondispersive interconnects [8903-42]

J. Ogrodzki, Warsaw Univ. of Technology (Poland)

8903 is Analog approach to mixed analog-digital circuit simulation [8903-43]

J. Ogrodzki, Warsaw Univ. of Technology (Poland)

8903 1T Energy balance in advanced audio coding encoder bit-distortion loop algorithm [8903-46] G. Brzuchalski, G. Pastuszak, Warsaw Univ. of Technology (Poland)

$89031 \mathrm{U}$ Efficient MATLAB simulation of the brusselator [8903-47]

K. Opalska, Warsaw Univ. of Technology (Poland) 
$89031 \mathrm{~V} \quad$ Hardware simulator of Caliste-SO detectors for STIX instrument [8903-51]

P. Podgórski, D. Ścisłowski, M. Kowaliński, Space Research Ctr. (Poland); T. Mrozek, Space Research Ctr. (Poland) and Univ. of Wrocław (Poland); M. Stęślicki, J. Barylak, A. Barylak, J. Sylwester, Space Research Ctr. (Poland); S. Krucker, G. J. Hurford, Univ. of Applied Sciences and Arts Northwestern Switzerland (Switzerland) and Univ. of California, Berkeley (United States); N. G. Arnold, Univ. of Applied Sciences and Arts Northwestern Switzerland (Switzerland); P. Orleański, Space Research Ctr. (Poland) and Univ. of Applied Sciences and Arts Northwestern Switzerland (Switzerland); A. Meuris, O. Limousin, O. Gevin, Commissariat à l'Énergie Atomique (France); O. Grimm, ETH Zürich (Switzerland); L. Ełesi, N. Hochmuth, M. Battaglia, A. Csillaghy, Univ. of Applied Sciences and Arts Northwestern Switzerland (Switzerland); I. W. Kienreich, A. Veronig, Univ. of Graz (Austria); S. Bloomfield, M. Byrne, Trinity College Dublin (Ireland); A. M. Massone, M. Piana, S. Giordano, Univ. of Genova (Italy); K. R. Skup, R. Graczyk, M. Michalska, W. Nowosielski, A. Cichocki, M. Mosdorf, Space Research Ctr. (Poland)

8903 IW Optimization of a broadband vector network analyzer calibration [8903-52]

L. J. Opalski, Warsaw Univ. of Technology (Poland)

$89031 \mathrm{R} \quad$ Remarks on parallel computations in MATLAB environment [8903-56]

K. Opalska, L. Opalski, Warsaw Univ. of Technology (Poland)

$89031 Y \quad$ Highlights from ALICE at LHC [8903-57]

M. Janik, Warsaw Univ. of Technology (Poland)

$89031 \mathrm{~A}$ ALICE: the heavy-ion experiment at the CERN/LHC [8903-58]

Ł. Graczykowski, Warsaw Univ. of Technology (Poland)

890320 Accelerators for society: succession of European infrastructural projects: CARE, EUCARD, TIARA, EUCARD ${ }^{2}$ [8903-61]

R. S. Romaniuk, Warsaw Univ. of Technology (Poland)

$890321 \quad$ Review of parallel computing methods and tools for FPGA technology [8903-62]

R. Cieszewski, M. Linczuk, K. Pozniak, R. Romaniuk, Warsaw Univ. of Technology (Poland)

890322 Hardware random number generator base on monostable multivibrators dedicated for distributed measurement and control systems [8903-64]

P. Czernik, Warsaw Univ. of Technology (Poland)

890323 SODE assisted analysis of deep metastability [8903-66]

L. J. Opalski, Warsaw Univ. of Technology (Poland)

$890324 \quad$ Visions for the future of particle accelerators [8903-73]

R. S. Romaniuk, Warsaw Univ. of Technology (Poland)

890325 Telemetry beacon for Polish payload on BRITE-PL-2 satellite [8903-83]

G. Woźniak, Nicolaus Copernicus Astronomical Ctr. (Poland); M. Stolarski, Space Research Ctr. (Poland)

890326 Design, modeling, and simulation of MEMS pressure sensors [8903-84]

M. Gęca, A. Kociubiński, Lublin Univ. of Technology (Poland) 
890327 Low-power cryptographic coprocessor for autonomous wireless sensor networks [8903-86] J. Olszyna, W. Winiecki, Warsaw Univ. of Technology (Poland)

890328 The GLORIA demonstrator experiment [8903-87]

A. Majcher, A. Ćwiek, National Ctr. for Nuclear Research (Poland); M. Ćwiok, Univ. of Warsaw (Poland); L. Mankiewicz, Ctr. for Theoretical Physics (Poland); M. Zaremba, A. F. Żarnecki, Univ. of Warsaw (Poland)

890329 Tests of the superconducting magnets, cavities, and cryomodules for the European XFEL [8903-97]

A. Kotarba, P. Borowiec, W. Daniluk, M. Duda, B. Dzieza, W. Gaj, E. Gornicki, D. Karolczyk

K. Kasprzak, L. Kolwicz-Chodak, J. Kotula, A. Krawczyk, K. Krzysik, W. Maciocha,

A. Marendziak, K. Myalski, Sz. Myalski, T. Ostrowicz, B. Prochal, M. Skiba, M. Stodulski,

J. Swierblewski, M. Wiencek, J. Zbroja, A. Zwozniak, The Henryk Niewodniczański Institute of Nuclear Physics (Poland)

8903 2A Implementation of PCle-SerDes-DDR3 communication in a multi-FPGA data acquisition system [8903-99]

A. Byszuk, P. Kolasiński, K. Poźniak, W. M. Zabołotny, G. Kasprowicz, Warsaw Univ. of Technology (Poland)

8903 2B Recent development in optimization of superconducting thin film lead photocathodes at NCBJ in Świerk [8903-105]

R. Nietubyć, J. Lorkiewicz, R. Mirowski, M. Barlak, J. Witkowski, National Ctr. for Nuclear Research (Poland); J. Sekutowicz, DESY (Germany); P. Kneisel, Thomas Jefferson National Accelerator Facility (United States)

8903 2C Vortex meter designing: Simulation or laboratory investigations? [8903-107]

G. L. Pankanin, Warsaw Univ. of Technology (Poland)

8903 2D FPGA based fast synchronous serial multi-wire links synchronization (Invited Paper) [8903-108]

K. T. Pozniak, Warsaw Univ. of Technology (Poland)

$89032 \mathrm{E} \quad$ Robust estimation of noisy signal parameter in radar applications [8903-109]

Z. Gajo, M. Linczuk, Warsaw Univ. of Technology (Poland)

8903 2F FPGA based charge fast histogramming for GEM detector (Invited Paper) [8903-110] K. T. Poźniak, A. Byszuk, Warsaw Univ. of Technology (Poland); M. Chernyshova, Institute of Plasma Physics and Laser Microfusion (Poland); R. Cieszewski, Warsaw Univ. of Technology (Poland); T. Czarski, Institute of Plasma Physics and Laser Microfusion (Poland); W. Dominik, Univ. of Warsaw (Poland); K. Jakubowska, Institute of Plasma Physics and Laser Microfusion (Poland); G. Kasprowicz, Warsaw Univ of Technology (Poland); J. Rzadkiewicz, Institute of Plasma Physics and Laser Microfusion (Poland) and National Ctr. for Nuclear Research (Poland); M. Scholz, Institute of Nuclear Physics (Poland); W. Zabolotny, Warsaw Univ. of Technology (Poland)

$89032 \mathrm{G}$ Information theory: two theories in one (Invited Paper) [8903-112]

A. Platonov, Warsaw Univ. of Technology (Poland) 
$89032 \mathrm{H} \quad$ Reduction of the influence of amplifier gain setting errors on the performance of adaptive ADC [8903-113]

Ł. Małkiewicz, Warsaw Univ. of Technology (Poland)

890321 Characterization of inkjet-printing HF and UHF antennas for RFID applications [8903-116]

G. Tarapata, D. Paczesny, K. Kawecki, Warsaw Univ. of Technology (Poland)

$89032 \mathrm{~J} \quad$ A new construction of measurement system based on specialized microsystem design for laryngological application [8903-117]

D. Paczesny, F. Mikłaszewicz, Warsaw Univ. of Technology (Poland)

8903 2K ALFA detector: timing and trigger [8903-118]

K. M. Korcyl, The Henryk Niewodniczański Institute of Nuclear Physics (Poland)

8903 2L How does life emerge out of chaos? [8903-119]

J. Grębosz, The Henryk Niewodniczański Institute of Nuclear Physics (Poland)

$89032 \mathrm{M}$ Methodology and technological aspects of the flexible substrate preparation for ink-jet printing technology [8903-120]

G. Tarapata, M. Marzęcki, Warsaw Univ. of Technology (Poland)

8903 2N Embedded controller for GEM detector readout system (Invited Paper) [8903-32]

W. M. Zabołotny, A. Byszuk, Warsaw Univ. of Technology (Poland); M. Chernyshova, Institute of Plasma Physics and Laser Microfusion (Poland); R. Cieszewski, Warsaw Univ. of Technology (Poland); T. Czarski, Institute of Plasma Physics and Laser Microfusion (Poland); W. Dominik, Univ. of Warsaw (Poland); K. L. Jakubowska, Institute of Plasma Physics and Laser Microfusion (Poland); G. Kasprowicz, K. Poźniak, Warsaw Univ. of Technology (Poland); J. Rzadkiewicz, Institute of Plasma Physics and Laser Microfusion (Poland) and National Ctr. for Nuclear Research (Poland); M. Scholz, Institute of Nuclear Physics (Poland)

890320 Consideration of component imperfections in new digitally assisted sub-ranging A/D converters [8903-34]

K. Jędrzejewski, Warsaw Univ. of Technology (Poland)

\section{COMPUTATIONAL INTELLIGENCE}

$89032 \mathrm{P} \quad$ Text converter to support legislative process [8903-38]

K. Woźniak, J. Mulawka, Warsaw Univ. of Technology (Poland)

$89032 \mathrm{Q}$ Algebraic logic of concepts and its machine implementation in the algebras of deontic and axiological notions (Invited Paper) [8903-44]

A. Manerowska, Warsaw Univ. of Technology (Poland); E. Nieznański, Łazarski Univ. in Warsaw (Poland); J. Mulawka, Warsaw Univ. of Technology (Poland)

$890325 \quad$ Implementation aspects of Graph Neural Networks [8903-88]

A. Barcz, Z. Szymański, S. Jankowski, Warsaw Univ. of Technology (Poland)

8903 2T Active learning of neural networks based on influential statistics [8903-106] G. Cuesta, C. Rio, Univ. Ramon Llull (Spain); S. Jankowski, Warsaw Univ. of Technology (Poland) 
$89032 U$ Another expert system rule inference based on DNA molecule logic gates [8903-25] P. Wasiewicz, Warsaw Univ. of Technology (Poland)

Author Index 


\title{
Conference Committee
}

\author{
Symposium Steering Committee
}

Andrzej W. Domański, Warsaw University of Technology (Poland Jan Dorosz, Bialystok University of Technology (Poland)

Leszek Jaroszewicz, Military University of Technology (Poland)

Jerzy Klamka, Elektronika, Association of Polish Electrical Engineers (Poland)

Lech Mankiewicz, Center for Theoretical Physics (Poland)

Ryszard S. Romaniuk, Warsaw University of Technology (Poland)

Jan Dorosz, Bialystok University of Technology (Poland)

Tomasz R. Woliński, Warsaw University of Technology (Poland)

Wiesław L. Woliński, Warsaw University of Technology (Poland)

Waldemar Wójcik, Lublin University of Technology (Poland)

Grzegorz Wrochna, National Center for Nuclear Research (Poland)

Symposium Chair

Ryszard S. Romaniuk, Warsaw University of Technology (Poland)

Symposium Committee

Tomasz Adamski, Warsaw University of Technology (Poland

Michał Borecki, Warsaw University of Technology (Poland)

Dominik Dorosz, Bialystok University of Technology (Poland)

Zbigniew Gołębiewski, National Center for Nuclear Research (Poland)

Antoni Grzanka, Warsaw University of Technology (Poland)

Stanisław Jankowski, Warsaw University of Technology (Poland)

Mirosław Karpierz, Warsaw University of Technology (Poland)

Lech Mankiewicz, Center for Theoretical Physics (Poland)

Jan Mulawka, Warsaw University of Technology (Poland)

Robert Nietubyć, National Center for Nuclear Research (Poland)

Jan Ogrodzki, Warsaw University of Technology (Poland)

Leszek Opalski, Warsaw University of Technology (Poland)

Anatoli Płatonow, Warsaw University of Technology (Poland)

Krzysztof T. Poźniak, Warsaw University of Technology (Poland)

Michał Ramotowski, Warsaw University of Technology (Poland)

Ryszard S. Romaniuk, Warsaw University of Technology (Poland)

Władysław Skarbek, Warsaw University of Technology (Poland)

Aleksander Filip Żarnecki, Warsaw University (Poland) 


\section{Session Chairs}

1 Photonics Applications and Web Engineering, XXXII Wilga 2013 Symposium

Ryszard S. Romaniuk, Warsaw University of Technology (Poland)

2 Optical Science and Technology

Lech Mankiewicz, Center for Theoretical Physics (Poland)

3 Satellite and Space Technology

Piotr Orleański, Space Research Center (Poland)

$4 \quad$ High Energy Physics Experiments

Piotr Malecki, Institute of Nuclear Physics (Poland)

Krzysztof T. Poźniak, Warsaw University of Technology (Poland)

5 Communications and Multimedia Technology

Władysław Skarbek, Warsaw University of Technology (Poland)

6 Optoelectronics Technologies, Components, Devices, and Systems

Michał Borecki, Warsaw University of Technology (Poland

$7 \quad$ Materials and Technologies

Małgorzata Suchańska, Kielce University of Technology (Poland)

8 Components and System Modeling

Leszek Opalski, Warsaw University of Technology (Poland)

Jan Ogrodzki, Warsaw University of Technology (Poland)

$9 \quad$ Biomedical and DNA Computing

Jan Mulawka, Warsaw University of Technology (Poland)

10 Airborne Applications of Computational Intelligence

Stanisław Jankowski, Warsaw University of Technology (Poland)

11 Artficial Intelligence, Cryptography, Software, and Ontological ITC Systems

Jan Mulawka, Warsaw University of Technology (Poland)

12 WILGA 2013 SPIE-PSP Best Student Paper Awards

Maciej Linczuk, Ryszard Kossowski, Michal Ramotowski, Warsaw University of Technology (Poland) 


\section{Introduction}

The WILGA Symposium [wilga.ise.pw.edu.pl] is a kind of international Forum of Young Science in Photonics, Advanced Electronics, and Internet Engineering. It is organized twice a year under the eminent patronage of two big international engineering institutions, SPIE [WwW.spie.org] and IEEE [Www.ieee.org], and their Polish counterparts, PSP-Photonics Society of Poland [Www.photonics.pl], successor of the Polish chapter of SPIE [www.spie.pl], and IEEE Poland Section [www.ieee.pl], with participation of IEEE R8 [www.ieeer8.org/]. The symposium is sponsored by PAS-Polish Academy of Science (The Committee on Electronics and Telecommunication) [www.keit.pan.pl], the Association of Polish Electrical Engineers (SEP) [www.sep.com.pl], Polish Committee of Optoelectronics SEP, Warsaw University of Technology [www.pw.edu.pl], and the Institute of Electronic Systems [www.ise.pw.edu.pl].

WILGA Organizers: The Symposium is organized by a group of devoted young people-photonics, mechatronics, and electronics researchers-gathered in the PERG/ELHEP Research Group of the Institute of Electronic Systems at the Warsaw University of Technology (WUT). Most of these young researchers are active members of PSP, SEP, SPIE, OSA and IEEE. The symposium is diligently run by young researchers for young fellow researchers, and the main aim is to have a lot of fun and to learn a lot.

WILGA Publications: The WILGA Symposium publishes its papers in the following proceedings series, technical and peer-reviewed journals: Proceedings of SPIE, since 2002; IEEE eXplore, Internet publication data base; Photonics Letters of Poland, since 2009; Elektronika, SEP Journal, since 1998; JET-International Journal of Electronics and Telecommunications, PAS. Wilga is sponsored by The EU FP7 EUCARD and TIARA.

WILGA Proceedings of SPIE: There has been a long tradition of WILGA publishing its works in the Proceedings of SPIE. This volume is the 13th published with WILGA papers. The WILGA-SPIE volume series contain more than 1,000 papers. All WILGA symposiums published more than 2,500 papers, with around 5,000 participants. This is an extraordinary achievement for a modest symposium oriented solely on young researchers. No one event of similar character could compare to this achievement. This success was only possible due to big involvement of young researchers in their work. The following WILGA Proc. SPIE were published: Wilga 2002 - Proc. SPIE 5125; Wilga 2003 - Proc. SPIE 5484; Wilga 2004 - Proc. SPIE 5775; Wilga 2005 bis - Proc. SPIE 5948; Wilga 2005 - Proc SPIE 6159; Wilga 2006 - Proc. SPIE 6347; Wilga 2007 - Proc. SPIE 6937; Wilga 2008 - Proc. SPIE 7124; Wilga 2009 Proc. SPIE 7502; Wilga 2010 - Proc. SPIE 7745; WILGA 2011 - Proc. SPIE 8008; WILGA 2012 - Proc. SPIE 8454; and the current volume from WILGA 2013 is Proc. SPIE 8903. 
SPIE Poland 2005: The SPIE Poland meetings in 2005 were very special because then the Polish Chapter of SPIE (predecessor of Photonics Society of Poland) hosted together with SPIE and some other regional SPIE Chapters, the SPIE Warsaw Congress on Optics and Optoelectronics - SPIE COO Warsaw 2005. WILGA 2005 Symposium was split to two parts - one held usually in WILGA and the second jointly with the COO'05.

WILGA ways and topics: The official language of the symposium is English. Peer reviewed papers are published in a renowned, worldwide recognized series, the Proceedings of SPIE. The symposium is designed mainly for Ph.D., M.Sc., and B.SC. students (from physics, electronics and mechatronics, as well as material research) and their tutors/mentors. WILGA has a number of main topical tracks. Historically, the first one was photonics and web engineering. Generally, WILGA embraces advanced photonic, mechatronic, and electronic systems, in the following aspects: theory, modeling, algorithms, simulations, emulations, design, hardware, software, hardware-software interaction and integration, measurements, testing, commissioning and exploitation. WILGA also addresses new research tendencies like 3D photonics and electronics design, micro- and nano-systems, material engineering including meta-materials.

Topical sessions are organized by leading experts. Sessions usually begin with current tutorials and are filled with contributed papers by students and young researchers. One of the most important session tracks in WILGA are photonics applications and systems for superconductive accelerator (and free electron laser) technology and high energy physics experiments.

WILGA XXXth Symposium: WILGA 2013, the February edition, was held on 8-9 February 2013 at the Warsaw University of Technology. The WILGA 2013 May edition was held on 27 May-2 June 2013 at a resort owned by Warsaw University of Technology. More than 300 presentations were delivered during both editions of Wilga, covering a broad area of photonics applications and web engineering. Nearly 350 persons participated. The exceptionally efficient chair of the Organization Committee of WILGA 2013 was Dr. Maciek Linczuk.

The working research sessions of 32nd WILGA 2013 were: general photonics, optical fiber technology, optical communications, optoelectronics, applications of optical fibers, integration of electronics, photonics and mechatronics, distributed measurement systems, LHC and CMS at CERN, JET and ITER photomasks, optics and optoelectronics for astronomy, fundamentals of FPGADSP systems, object oriented design of hardware, terabit optical data links, software-hardware co-design, biomedical engineering, computational intelligence of advanced systems, development of photonics and electronics in Europe and Poland, radar technology, terahertz photonics, free electron lasers, EXFEL and POLFEL lasers, EUCARD-European Coordination of Accelerator Research and Development, and TIARA, etc. A special session was devoted to a project EuCARD2 (2013-2017), which is a continuation of EuCARD. 
WILGA offspring: The WILGA Symposium gave birth to a few topical meetings and conferences which then struck out on their own. These include student regional meetings (Opole, Wrocław, Kielce, Białystok, Lublin, Toruń, et al.) of SPIE student chapters and IEEE student branches, but also stand-alone conferences. Some of these meetings are still held periodically with Wilga, while some of them gained complete independence. WILGA is very proud of this 'parentship,' since the very good idea of WILGA is proliferating elsewhere. One of such meetings is, now fully independent, SPS - Signal Processing Symposium, which began at Wilga in 2003.

SPIE - PSP WILGA 2014: The organizers of the WILGA 2014 Symposium, to be held 26 May-1 June 2014, warmly invite interested young researchers and students in photonics and related fields to participate in this exceptional and friendly research event oriented to host young researchers from Poland and all over Europe.

\section{References}

1. WILGA 2002: R.S.Romaniuk, K.T.Poźniak (editors), Proc. SPIE 5125; Photonics Applications in Astronomy, Communications, Industry, and High-Energy Physics Experiments 2002; ISBN 9780819449856; 472 pages, 55 papers; (2003)

2. WILGA 2003: R.S.Romaniuk (editor), Proc.SPIE 5484; Photonics Applications in Astronomy, Communications, Industry, and High-Energy Physics Experiments 2003; ISBN 9780819454157; 734 pages, 94 papers; (2004)

3. WILGA 2004: R.S.Romaniuk (editor). Proc. SPIE 5775; Photonics Applications in Astronomy, Communications, Industry, and High-Energy Physics Experiments 2005; ISBN 9780819457561; 710 pages, 92 papers; (2005)

4. WILGA 2005 bis: R.S.Romaniuk, S.Simrock, V.M.Lutkovski (editors), Proc. SPIE 5948, Photonics Applications in Industry and Research 2005; ISBN 9780819459558; 864 pages, 89 papers; (2005)

5. WILGA 2005: R.S.Romaniuk (editor), Proc. SPIE 6159; Photonics Applications in Astronomy, Communications, Industry, and High-Energy Physics Experiments 2005; ISBN 9780819462114; 1244 pages, 172 papers; (2006)

6. WILGA 2006: R.S.Romaniuk (editor), Proc. SPIE 6347; Photonics Applications in Astronomy, Communications, Industry, and High-Energy Physics Experiments 2006; ISBN 9780819464316; 874 pages, 111 papers; (2006)

7. WILGA 2007: R.S.Romaniuk (editor), Proc. SPIE 6937; Photonics Applications in Astronomy, Communications, Industry, and High-Energy Physics Experiments 2007; ISBN 9780819471246; 1274 pages, 152 papers; (2008)

8. WILGA 2008: R.S.Romaniuk, T.R.Woliński (editors), Proc. SPIE 7124; Photonics Applications in Astronomy, Communications, Industry, and High-Energy Physics Experiments 2008; ISBN 9780819473585; 312 pages, 35 papers; (2008)

9. WILGA 2009: R.S.Romaniuk, K,S.Kulpa (editors), Proc. SPIE 7502; Photonics Applications in Astronomy, Communications, Industry, and High-Energy Physics Experiments 2009; ISBN 9780819478139; 786 pages, 100 papers; (2009) 
10. WILGA 2010: R.S.Romaniuk (editor), Proc. SPIE 7745; Photonics Applications in Astronomy, Communications, Industry, and High-Energy Physics Experiments 2010; ISBN 9780819464316; 650 pages, 73 papers; (2010)

11. WILGA 2011: R.S.Romaniuk (editor), Proc. SPIE 8008; Photonics Applications in Astronomy, Communications, Industry, and High-Energy Physics Experiments 2011; ISBN 9780819464316; 500 pages, 70 papers; (2011)

12. WILGA 2012: R.S.Romniuk (editor), Proc. SPIE 8454; Photonics Applications in Astronomy, Communication, Indutry, and High Energy Physics Experiments 2012: ISBN 9780819491718; 600 pages, 90 papers (2012)

13. WILGA 2013: R.S.Romniuk (editor), Proc. SPIE 8903; Photonics Applications in Astronomy, Communication, Industry, and High Energy Physics Experiments 2013: ISBN 9780819497857

14. J.Dorosz, R.Romaniuk, The role of regional developments in optical fiber technology and photonics, Proc. SPIE 5028, 2003, pp.xi-xii

15. R.Romaniuk, K.Pozniak, Foreword: Photonics and electronics for astronomy and high energy physics experiments in Poland, Proc.SPIE 5125, 2002, pp.xiii-xxxiv

16. W.Woliński, Z.Jankiewicz, R.Romaniuk, Proceedings of SPIE - The International Society for Optical Engineering: Introduction, Proc. SPIE 5230, 2003, pp.ix-x

17. R.Romaniuk, Proceedings of SPIE - The International Society for Optical Engineering: Introduction, Proc. SPIE 5775, 2005, pp.xxi-xxvii

18. R.Romaniuk, Proceedings of SPIE - The International Society for Optical Engineering: Introduction, Proc. SPIE 5848, 2005, pp.xvii-xxi

19. R,Romaniuk, Proceedings of SPIE - The International Society for Optical Engineering: Introduction, Proc. SPIE 6347, 2006, pp.xxix-xxxii

20. W.Wolinski, Z.Jankiewicz, R.Romaniuk, Proceedings of SPIE - The International Society for Optical Engineering: Introduction, Proc. SPIE 6598, 2007, pp.ix-xii

21. R.Romaniuk, Proceedings of SPIE - The International Society for Optical Engineering: Introduction, Proc. SPIE 6937, 2008, pp.xxix-xli

22. W.Woliński, Z.Jankiewicz, R.Romaniuk, Proceedings of SPIE - The International Society for Optical Engineering: Introduction, Proc. SPIE 5229, 2003, pp.xi-xii

23. J.Dorosz, R.Romaniuk, T.Wolinski, Eleventh conference on optical fibers and their applications, Proc. SPIE 7120, 2008, pp.xiii-xv

24. R.Romaniuk, K,Kulpa, Photonics applications in Astronomy, Communications Industry and High-Energy Physics Experiments 2009: Introduction, Proc. SPIE 7502, 2009, art no 750201, pp.xxiii-xxiv

25. R.Romaniuk, Photonics and Web Engineering in Poland, WILGA 2009, Proc. SPIE 7502, 2009, art no. 750202

26. R.Romaniuk, WILGA Symposium on photonics applications, Photonics Letters of Poland 1 (2), 2009, pp.46-48

27. R.S.Romaniuk, Wilga 2010, Photonics Applications, Proc.SPIE 7745, pp.xiii-xviii, 2010

28. R.S.Romaniuk, Wilga 2011, Photonics Applications, Proc.SPIE 8008, pp.xii-xviii, 2011

29. R.S.Romaniuk, Wilga 2012, Photonics Applications, Proc.SPIE 8454, pp.vii-x, 2012

Ryszard S. Romaniuk

xviii 